\title{
The implementation of Lean Six Sigma for operational excellence in digital emerging technology companies
}

Lameijer, Bart; University of Amsterdam; b.a.lameijer@uva.nl Pereira, Wilmer; San Francisco State University; pereira@sfsu.edu Antony, Jiju; Heriot Watt University; j.antony@hw.ac.uk

\begin{abstract}
Purpose: The purpose of this research is to develop a better understanding of the hurdles in implementing Lean Six Sigma (LSS) for operational excellence in digital emerging technology companies.

Design: We have conducted case studies of LSS implementations in six United States based companies in the digital emerging technology industry.

Findings: Critical success factors (CSF) for LSS implementations in digital emerging technology companies are: (1) organizational leadership that is engaged to the implementation, (2) LSS methodology that is rebranded to fit existing shared values in the organization, (3) restructuring of the traditional LSS training program to include a more incremental, prioritized, on-the-job training approach, and (4) a modified LSS project execution methodology that includes (a) condensing the phases and tools applied in LSS projects, and (b) adopting more iterative project management methods compared to the standard phased LSS project approach.

Implications: Implications comprise the awareness and knowledge of critical success factors and LSS methodology modifications specifically relevant for digital emerging technology companies or companies that share similarities in terms of focus on product development, innovation and growth, such as R\&D departments in high-tech manufacturing companies.
\end{abstract}

Limitations: The qualitative nature of our analysis and the geographic coverage of our sample limits the generalizability of our findings.

Originality: Research on industry specific enablers for successful LSS implementation in the digital emerging technology industry is virtually absent. Our research informs practitioners on how to implement LSS in this and alike industries, and points to aspects of such implementations that are worthy of further attention from the academic community.

Keywords: Six Sigma, Lean Management, Digital Technology, Implementation 


\section{Introduction}

In recent years, companies in digital technology industries have experienced rapid growth, due to among other reasons, the fast penetration of worldwide internet availability. Digital technology companies are traditionally defined as "businesses that provide a digital technical service/ product/ platform/ hardware, or heavily rely on it, as its primary revenue source" (Tech Nation, 2016). The digital technology industry however comprises several categories, such as the development of software (12\%), devices and infrastructure (23\%), IT and business services (21\%), telecom services (26\%) and finally emerging technologies (19\%) (CompTIA, 2020). Companies categorized under "emerging technologies" are, or for long have been, involved in technologies that span multiple categories, as is the case for most emerging as-aservice solutions that include elements of hardware, software and services, which currently comprises amongst others Internet of Things applications, experimentation with the use drones and many other recent automation technologies.

The consequence of the rapid growth in this industry is an entrepreneurial focus on product development, human resource attraction and retainment and financing needs to support further growth. When companies transcend the initial start- and scale-up phases and become established, public scrutiny will increase. Stakeholders from capital markets, governments and society will impose demands on profitability and internal efficiency, regulatory compliance and legitimate corporate conduct. Hence, the control and optimization of processes becomes more important. Strategies used by companies to adequately respond to such demands comprise a focus on operational excellence and by the implementation of well-known operational excellence methodologies such as Lean management and/ or Six Sigma companies aim to eliminate operational inefficiencies and enhance operational control (Delgado et al. 2010).

In recent years the Lean and Six Sigma methodologies are applied and studied as one (Shah et al., 2008). Nevertheless, Lean Six Sigma (LSS) has a long history of development and was popularized in the production sector by companies such as Toyota, Motorola and General Electrics in the mid and late $20^{\text {th }}$ century (Shah et al., 2008). Ever since, the methodology has been widely implemented in sectors such as finance, healthcare and public administration. Research on such implementations revealed that industry idiosyncrasies call for modifications of the methodology for effective implementation (Antony et al., 2020; Sreedharan and Raju, 2016).

The digital emerging technology (DE-TECH) industry is rapidly growing both in size and importance for everyday societal lives. Broader information technology industry trends reveal that the portion of economic activity resulting from this sector is outgrowing traditional sectors such as retail, construction and transportation (CompTIA, 2020). In recent years, an increasing appetite for LSS implementation in DE-TECH companies is observed (PEX, 2019; McKinsey, 2014). However, the research on LSS implementation in this industry is virtually absent. In this research, we aim to develop a better understanding of the hurdles in implementing Lean Six Sigma (LSS) for operational excellence in DE-TECH companies. We do so by (1) identifying the idiosyncrasies relevant for the implementation of LSS; (2) observing modifications of the LSS methodology in effective implementations and; (3) exploring the complementarities of data analytical capabilities that naturally exist in DE-TECH companies, with analytical techniques used in LSS implementations. 
This paper presents the results from multiple case studies of companies in the DETECH industry that have commenced LSS implementation. Within- and cross case analysis is performed based on in-depth semi-structured interviews with LSS implementation leaders and practitioners. First, this study explores critical success factors. We find prevalent critical success factors that have previously been identified in the literature, such as leadership that is engaged to the implementation, LSS methodology that is rebranded to fit existing shared values in the organization and finally a restructuring of the LSS training approach whereby a more incremental, prioritized, on-the-job training approach is applied. Other findings are newly identified, such as often seen modifications of the structured LSS project method by consolidation of specific phases or tools in LSS projects and the application of more iterative project management methods. We find limited complementarities and amendments to LSS's existing statistical toolbox and finally, implications for practice and future research are presented. 
Anand, G., Ward, P. T., Tatikonda, M. V. and Schilling, D. A. (2009), Dynamic capabilities through continuous improvement infrastructure, Journal of Operations Management, Vol. 27 No. 6, pp. 444-461.

Ansari, S. M., Fiss, P. C. and Zajac, E. J. (2010), Made to fit: How practices vary as they diffuse, Academy of management review, Vol. 35 No. 1, pp. 67-92.

Antony, J., Laux, C., Cudney, E. A. (2020), The Ten Commandments of Lean Six Sigma - a guide for practitioners, Emerald Publishing, UK

American Society for Quality (2019), https://asq.org/cert/six-sigma-black-belt, Visited: 28-82019

Azevedo, A. I. R. L. and Santos, M. F. (2008), KDD, SEMMA and CRISP-DM: a parallel overview, IADS-DM.

Bartlett, R. (2013), A practitioners guide to business analytics: Using data analysis tools to improve your organization's decision making and strategy, McGraw Hill Professional.

Bhasin, S. (2013), Impact of corporate culture on the adoption of the Lean principles, International Journal of Lean Six Sigma, Vol. 4 No. 2, pp. 118-140.

Chiarini, A. and Bracci, E. (2013), Implementing lean six sigma in healthcare: issues from Italy, Public Money \& Management, Vol. 33 No. 5, pp. 361-368.

Choo, A.S., Linderman, K.W. and Schroeder, R.G. (2007a), Method and psychological effects on learning behaviors and knowledge creation in quality improvement projects, Management Science, Vol. 53 No. 3, pp.437-50.

Choo, A. S., Linderman, K. W. and Schroeder, R. G. (2007b), Method and context perspectives on learning and knowledge creation in quality management, Journal of Operations Management, Vol. 25 No. 4, pp. 918-931.

Computer Technology Industry Association. (2020). "Industry Outlook 2021”, available at: https://www.comptia.org/content/research/it-industry-trends-analysis

Coronado, R.A. and Antony, J. (2002), Critical success factors for the successful implementation of Six Sigma projects in organizations, The TQM Magazine, Vol. 14 No. 2, pp.92-99.

Correia, A., Gonçalves, A. and Misra, S. (2019, July), Integrating the Scrum Framework and Lean Six Sigma, In International Conference on Computational Science and Its Applications. pp. 136-149. Springer, Cham.

Davenport, T. (2014), Big data at work: dispelling the myths, uncovering the opportunities, Harvard Business Review Press.

De Koning, H. and De Mast, J. (2006), A rational reconstruction of Six-Sigma's breakthrough cookbook, International Journal of Quality \& Reliability Management, Vol. 23 No. 7, pp. 766787.

De Koning, H., Does, R. J. and Bisgaard, S. (2008), Lean Six Sigma in financial services, International Journal of Six Sigma and Competitive Advantage, Vol. 4 No. 1, pp. 1-17.

Delgado, C., Ferreira, M. and Castelo Branco, M. (2010), The implementation of lean Six Sigma in financial services organizations, Journal of Manufacturing Technology Management, Vol. 21 No. 4, pp. 512-523. 
De Mast, J. and Lokkerbol, J. (2012), An analysis of the Six Sigma DMAIC method from the perspective of problem solving, International Journal of Production Economics, Vol. 139 No. 2, pp. 604-614.

Eisenhardt, K. M. and Graebner, M. E. (2007), Theory building from cases: Opportunities and challenges, Academy of Management Journal, Vol. 50 No. 1, pp. 25-32.

Estay, C., Durrieu, F. and Akhter, M. (2013), Entrepreneurship: From motivation to start-up, Journal of International Entrepreneurship, Vol. 11 No. 3, pp. 243-267.

Fayyad, U., Piatetsky-Shapiro, G. and Smyth, P. (1996), From data mining to knowledge discovery in databases, AI magazine, Vol. 17 No. 3, pp. 37-37.

Ghane, K. (2014), A model and system for applying Lean Six sigma to agile software development using hybrid simulation, In 2014 IEEE International Technology Management Conference (pp. 1-4). IEEE.

Hagen, M. (2010), Black Belt coaching and project outcomes: An empirical investigation, Quality Management Journal, Vol. 17 No. 2, pp.54-67.

Hayler, R. and Nichols, M. (2005), What is Six Sigma Process Management? McGraw-Hill Education.

Heckl, D., Moormann, J. and Rosemann, M. (2010), Uptake and success factors of Six Sigma in the financial services industry, Business Process Management Journal, Vol. 16 No. 3, pp. 436-472.

Hilton, R. J. and Sohal, A. (2012), A conceptual model for the successful deployment of Lean Six Sigma, International Journal of Quality \& Reliability Management, Vol. 29 No. 1, pp. 5470.

Jarr, S. (2015), Fast data and the new enterprise data architecture, O’Reilly Publishing.

Jurburg, D., Viles, E., Tanco, M. and Mateo, R. (2017), What motivates employees to participate in continuous improvement activities? Total Quality Management \& Business Excellence, Vol. 28 No. 13-14, pp. 1469-1488.

Kappelman, L.A., McKeeman, R., Zhang, L. (2006), Early warning signs of IT project failure: The dominant dozen, Information Systems Management, Vol. 23 No. 4, pp. 31-36.

Kwak, Y. H. and Anbari, F. T. (2006), Benefits, obstacles, and future of six sigma approach, Technovation, Vol. 26 No. 5-6, pp. 708-715.

Langstrand, J. and Drotz, E. (2016), The rhetoric and reality of Lean: a multiple case study, Total Quality Management \& Business Excellence, Vol. 27 No. 3-4, pp. 398-412.

Lameijer, B. A., Antony, J., Chakraborty, A., Does, R. J. M. M. and Garza-Reyes, J. A. (2020), The role of organisational motivation and coordination in continuous improvement implementations: an empirical research of process improvement project success, Total Quality Management \& Business Excellence, pp. 1-17.

Langabeer, J. R., DelliFraine, J. L., Heineke, J. and Abbass, I. (2009), Implementation of Lean and Six Sigma quality initiatives in hospitals: A goal theoretic perspective, Operations Management Research, Vol. 2 No. 1-4, pp. 13-27.

Laureani, A. and Antony, J. (2012), Critical success factors for the effective implementation of Lean Sigma: Results from an empirical study and agenda for future research, International Journal of Lean Six Sigma, Vol. 3 No. 4, pp. 274-283. 
Laureani, A. and Antony, J. (2018), Leadership-a critical success factor for the effective implementation of Lean Six Sigma, Total Quality Management \& Business Excellence, Vol. 29 No. 5-6, pp. 502-523.

Liedtka, J. (2018), Why design thinking works, Harvard Business Review, 96(5), 72-79.

Linderman, K., Schroeder, R.G., Zaheer, S. and Choo, A.S,, (2003), Six Sigma: a goal theoretic perspective, Journal of Operations Management, Vol. 21 No. 2, pp.193-203.

Linderman, K., Schroeder, R.G. and Choo, A.S. (2006), Six Sigma: The role of goals in improvement teams, Journal of Operations Management, Vol. 24 No. 6, pp.779-90.

McKinsey. (2014), "When Toyota met e-commerce: Lean at Amazon", available at: https://www.mckinsey.com/business-functions/operations/our-insights/when-toyota-met-ecommerce-lean-at-amazon

McLean, R.S., Antony, J., Dahlgaard, J.J. (2017), Failure of continuous improvement initiatives in manufacturing environments: A systematic review of the evidence, Total Quality Management \& Business Excellence, Vol. 28 No. 3-4, pp. 219-237.

Megahed, F. M. and Jones-Farmer, L. A. (2015), Statistical perspectives on "big data", In Frontiers in statistical quality control, Vol. 11, pp. 29-47. Springer, Cham.

Miles, M. B., Huberman, A. M., Huberman, M. A. and Huberman, M. (1994), Qualitative data analysis: An expanded sourcebook. Sage.

Moen, R. and Norman, C. (2006), Evolution of the PDCA cycle.

Netland, T. H. and Aspelund, A. (2013), Company-specific production systems and competitive advantage: a resource-based view on the Volvo production system. International Journal of Operations \& Production Management, Vol. 33 No. 11-12, pp. 1511-1531.

Netland, T. H. (2016), Critical success factors for implementing lean production: the effect of contingencies, International Journal of Production Research, Vol. 54 No. 8, pp. 2433-2448.

Null, G., Cross, J. A. and Brandon, C. (2019), Effects of Lean Six Sigma in program management, Journal of Manufacturing Technology Management, Vol. 31 No. 3, pp. 572-598.

O'Reilly III, C. A. and Tushman, M. L. (2013), Organizational ambidexterity: Past, present, and future, Academy of Management Perspectives, Vol. 27 No. 4, pp. 324-338.

Panizzolo, R., Garengo, P., Sharma, M. K. and Gore, A. (2012), Lean manufacturing in developing countries: evidence from Indian SMEs, Production Planning \& Control, Vol. 23 No. 10-11, pp. 769-788.

Patton, E. and Appelbaum, S. H. (2003), The case for case studies in management research, Management Research News, Vol. 26 No. 5, pp. 60-71.

Process Excellence Network. (2019), "Innovation and Process Improvement at Google", available at: https://www.processexcellencenetwork.com/lean-six-sigma-businessperformance/podcasts/innovation-and-process-improvement-at-google?ty-ur

Raval, S. J., Kant, R. and Shankar, R. (2018), Revealing research trends and themes in Lean Six Sigma: from 2000 to 2016, International Journal of Lean Six Sigma, Vol. 9 No. 3, pp. 399-443.

Ries, E. (2011), The Lean Startup. How Today's Entrepreneurs Use Continuous Innovation to Create Radically Successful Businesses, New York: Crown Business. 
Saad, S., Perera, T., Achanga, P., Shehab, E., Roy, R. and Nelder, G. (2006), Critical success factors for Lean implementation within SMEs, Journal of Manufacturing Technology Management. Vol. 17 No. 4, pp. 460-471.

Schroeder, R.G., Linderman, K., Liedtke, C. and Choo, A.S. (2008), Six Sigma: Definition and underlying theory, Journal of Operations Management, Vol. 26 No. 4, pp. 536-54.

Schwaber, K. and Sutherland, J. (2017), The Scrum Guide: The Definitive Guide to Scrum: The Rules of the Game. (2011), Available at: www.scrum.org.

Shah, R., Chandrasekaran, A. and Linderman, K. (2008), In pursuit of implementation patterns: the context of Lean and Six Sigma, International Journal of Production Research, Vol. 46 No. 2, pp.6679-99.

Shah, R. and Ward, P. T. (2003), Lean manufacturing: context, practice bundles, and performance, Journal of Operations Management, Vol. 21 No. 2, pp. 129-149.

Sousa, R. and Voss, C. A. (2008), Contingency research in operations management practices, Journal of Operations Management, Vol. 26 No. 6, pp. 697-713.

Spear, S. and Bowen, H. K. (1999), Decoding the DNA of the Toyota production system, Harvard Business Review, Vol. 77 No. 5, pp. 96-106.

Sreedharan, V. R. and Raju, R. (2016), A systematic literature review of Lean Six Sigma in different industries, International Journal of Lean Six Sigma, Vol. 7 No. 4, pp. 430-466.

Sreedharan, R., Sunder, V. M. and Raju, R. (2018), Critical success factors of TQM, Six Sigma, Lean and Lean Six Sigma: A literature review and key findings, Benchmarking: An international journal, Vol. 25 No. 9, pp. 3479-3504.

Strauss, A. and Corbin, J. (1990), Basics of Qualitative Research: Grounded Theory Procedures and Techniques, Sage, Newbury Park, CA.

Tech Nation. (2016), “Tech Nation Report 2016”, available at:

https://technation.io/insights/tech-nation-2016/

Taner, M. T., Sezen, B. and Antony, J. (2007), An overview of six sigma applications in healthcare industry, International Journal of Health Care Quality Assurance, Vol. 20 No. 4, pp. 329-340.

Van den Heuvel, J., Does, R. J. and De Koning, H. (2006), Lean Six Sigma in a hospital, International Journal of Six Sigma and Competitive Advantage, Vol. 2 No. 4, pp. 377-388.

Van der Aalst, Wil. (2011), Process mining: discovery, conformance and enhancement of business processes, Vol. 2, Heidelberg: Springer.

Vashishth, A., Chakraborty, A. and Antony, J. (2019), Lean Six Sigma in financial services industry: a systematic review and agenda for future research, Total Quality Management \& Business Excellence, Vol. 30 no. 3-4, pp. 447-465.

Voss, C., Tsikriktsis, N. and Frohlich, M. (2002), Case research in operations management, International Journal of Operations \& Production Management, Vol. 22 No. 2, pp. 195-219.

Wang, X., Conboy, K. and Cawley, O. (2012), "Leagile” software development: An experience report analysis of the application of lean approaches in agile software development, Journal of Systems and Software, Vol. 85 No. 6, pp. 1287-1299.

Womack, J.P., Jones, D.T. and Roos, D. (1990), The machine that changed the world. Simon and Schuster. 
Yin, R. K. (2017), Case study research and applications: Design and methods, Sage publications.

Zbaracki, M. J. (1998), The rhetoric and reality of total quality management, Administrative Science Quarterly, pp. 602-636.

Zu, X., Fredendall, L.D. and Douglas, T.J. (2008), The evolving theory of quality management: The role of Six Sigma, Journal of Operations Management, Vol. 26 No. 5, pp.630-50.

Zwetsloot, I. M., Kuiper, A., Akkerhuis, T. S. and de Koning, H. (2018), Lean Six Sigma meets data science: Integrating two approaches based on three case studies, Quality Engineering, Vol. 30 No. 3, pp. 419-431. 